\title{
TURKEY'S DIFFERENT PROBLEMS IN THREE PERIODS OF THREE WOMEN'S WORKS IN THE CONTEXT OF SOCIAL GENDER ROLES OF WOMEN WRITERS
}

\author{
Gizem Şahin $^{1^{*}}$ \\ ${ }^{1}$ Ms., Gazi University, Turkey, sahin.gizemm0635@gmail.com \\ *Corresponding author
}

\begin{abstract}
The position of women in society, women's role in society has always been debated along with men. In Turkey as well, there has been a lot of discussion on the women's social position. The main aim of this study is to evaluate women's issues in the context of gender roles by focusing on the novels of three writers from different periods of Turkish political history. In this study, first the Ottoman era writer Fatma Aliye Hanım's novel "Muhadarat", then the Republican era writer Adalet Ağaoğlu's novel "Ölmeye Yatmak", finally contemporary writer Ayfer Tunç's novel "Yeşil Peri Gecesi" have been analysed over the gender roles of their characters. We have chosen only one novel of each writer not to exceed the time limit of the congress report. In the scope of this research, a literature review was done and it was observed from the works reviewed that, in general, comments were made about single period of time. Moreover, the purpose of addressing different time periods is to examine changes in women's issues throughout the history and changes in the social structure over the concepts such as female-male relations, family, social gender, work, politics and freedom, through the characters of novels. Even though, women 's problems still exist, the results indicate that women have changed the social perception by increasing awareness, as a result of their efforts. In conclusion, this paper facilitates understanding by providing an opportunity to compare the social opinion of three writers from different periods and by showing the progress which writers have made. Providing an opportunity for interdisciplinary vision, literature and social structure can also give convenience for researchers from different disciplines in their future studies.
\end{abstract}

Keywords: Women Writers, Gender, Turkey.

\section{INTRODUCTION}

Women's role in society has always been debated along with men. Women who are from different societies, have started movements for rights in different historical periods. Due to women 's unequal position in labour relations, especially capitalism, have triggered these movements. Women's position is not only their home, but also society. Pioneer women want to change the perception about women and in their economic position. They also show on their own in social and cultural life. There have been many discussions about women movements and women's position in society, in Turkey, too. These discussions have occurred in literature, as well. Women 's problems that date back to the Turkish Republic from Ottoman Empire are evaluated by means of pioneer women writers' novels that are from different periods, in this study. Different periods were 
chosen to show changes which were about women 's movements and social structure in historical periods. Furthermore, these changes were examined the concepts such as female-male relations, family, social gender, work, politics and freedom, through the characters of novels. Since this study evaluated women's problems in different time periods, this study provided an opportunity to compare different time periods. Therefore, this study makes a difference. Only one novel of each writer was chosen in this research. One reason was not to digress the topic. Another reason was not to exceed the time limit of congress report. For this purpose, Fatma Aliye Hanım's novel "Muhadarat", Adalet Ağaoğlu's novel "Ölmeye Yatmak" and Ayfer Tunç's novel "Yeşil Peri Gecesi" were chosen. In this scope of this research, a literature review was done and it was observed from the works reviewed that, in general, comments were made about the single period of time. In conclusion, this research presents literate and social opinions of three writers. As the literature and social structure provide an opportunity between various disciplines, this study can also make it convenient for researchers from various disciplines in their future studies.

\section{WOMEN, IN TERMS OF FAMILY AND SOCIAL GENDER ROLES}

Family is one of the most important institutions because it points changes on social structure. In addition, the first area people become socialized is family. The family is also an indicator of power relations which between women and men, to rule the roost. Thanks to rule the roost, that is this power relation, changes on family and social life can be observed.

The family structure of the Ottoman Empire was based on extended family. Fatma Aliye Hanım was a member of extended family whose father was a famous historian and politician Ahmet Cevdet Pasha. As she was Ahmet Cevdet Pasha 's daughter, she had the chance because of her inquiring mind. People thought of women only as mother or wife in that period. But Fatma Aliye broke the taboos. Her father Ahmet Cevdet Pasha contributed to his daughter for her success, too. Ahmet Cevdet Pasha was interested in the education of his wife and daughters so that his daughters, Fatma Aliye and Emine Semiyye, became a pioneer in their period. Thanks to their good education, Fatma Aliye and Emine Semiyye became authors, wrote many essays and novels. They also participated in associations then they started women's solidarity as a member of these associations. İlber Ortaylı evaluates women's this solidarity movement that is started by Fatma Aliye and Emine Semiyye, as modernization. But this modernization is different from western civilisation. Because this modernization movement arises the Ottoman's own social dynamics (Ortaylı, 2013, s. 82).

When we talk about modernization, it is necessary to mention about the Tanzimat Reform Era. When western countries improved their technical infrastructure and their progress with Industrial Revolution, the Ottoman Empire noticed that its progress had gotten behind in western countries' this reason, the Ottoman Empire declared the Edict of Gülhane, also known as the Tanzimat.These reforms caused many discussions. As the Ottoman Empire was one of the strongest countries. There were many discussions about reforms in the Tanzimat Era literature. Reasons of these discussions rooted in concern. How did reforms shape the Ottoman society's customs? At this point, the Tanzimat 's authors interpret this concern through their characters of novels. For instance, these male characters try to become westernized, but they misunderstand westernization. While The Tanzimat 's authors characterize the east as masculine, they characterize the West as feminine. Thus, they characterize women as passive. But problem stem from men, as men are influenced not their culture, but are influenced different culture. Finally, the main concern is how new identity impress society (Gürbilek, 2014, s. 47).

Contrary to popular belief, Fatma Aliye emphasizes in her novels that life style doesn't prevent women. She also emphasizes that women don't know their own history. For this purpose, she gives examples of successful Muslim women in history. She succeeds changing foreigner authors' perception about Muslim women (Çakır, 2011, s. 71).

Fatma Aliye, mentions women's problems with her novel "Muhadarat". The main character of Muhadarat is Fazıla.Fazıla lives with her father Sai Efendi and with her brother Şefik.Her mother dies, when Fazıla is a child. But a friend of her mother, Münevver Hanım,behaves Fazıla and Şefik, as a mother. Then Fazıla in her older ages gets engaged with Münevver Hanım's son, Mukaddem.Mukaddem and Fazıla love each other, during childhood. But Fazıla's step mother, prevents them. Then Fazıla marries another man. Yet this marriage ends up in a bad way, Fazıla becomes odalisque. In terms of family roles, father -daughter relation, Fazıla and her father have a good relation, so she always listens to her father's suggestions. Even though Fazıla loves Mukaddem,she gets married another man.Obviously, her father doesn't want her to marry Mukaddem.Fatma Aliye believes that the family 's approval of the marriage is important.Fatma Aliye supports this belief on Fazıla,too.In terms of family roles, brother-sister relations,Fazıla behaves her brother Şefik, like his mother.Fatma Aliye 's Fazıla is a well behaved daughter and sister.Although her husband doesn't love her, she is thoughtful of him.Fatma Aliye presents her idea about love,as well. She thinks that love is 
temporary. Fazila and Mukaddem's love also is temporary. Even though they meet again, they love each other, as friends.

Fatma Aliye Hanım criticizes that people are forced into marriage and prearranged marriage on her novels. Fatma Aliye suggests people get their parents' approval, when they decide to marry. Moreover, sentimental value is important rather than appearance in marriage. In her opinion love prevent clear thinking, so she suggests people prefer clear thinking in their marriage (Yumuşak, 2010, s. 87).

The Republican Era, found a new nation state from the Ottoman Empire. Many reforms have been created in social arena. The family structure of society was also changed. Code of Civil Law was adopted on 17 February 1926. With adoption of civil law, polygamy was banned, marriageable age was determined. Although authorities gave importance equality between women and men, authorities were criticized for some provisions. One provision was, for example, when women wanted to work, it was necessary for their husband approval. Another provision was that ruler the root was husband (Arat, 1998, s. 56). The Republican authorities were also criticized that authorities and public had different assets. When authorities moved according to westernization, public was in a dilemma between westernization movements and traditional assets. Adalet Ağaoğlu criticizes authorities and this situation in her novels. Since Adalet Ağaoğlu was born in early ages the Republican era, she had an opportunity to evaluate both the Republican and the Ottoman Era. She analysed both era very well. She tells Aysel 's story in her novel "Ölmeye Yatmak". Aysel wants to have a good education. Finally, her dream comes true. Furthermore, Ağaoğlu tells problems of the Republican Era's generation, political environment between the Ottoman Era to Republican Era with her novel main character Aysel.On the one hand authorities make reforms with announcement of the Republic, on the other hand public keep up with reforms. For instance, while Aysel represents the Republican's generation, her father Salim Efendi, who was a tradesman, represents public which lives traditional values. Although Salim Efendi was İsmet Pasha's solder in Turkish War of Independence, he got angry with both authorities and his town, because he was punished due to economic environment of 1940s.After this event, Aysel and her family move to Ankara. As Salim Efendi is opponent, this effects Aysel 's life in a negative way. In terms of family roles, father-daughter relations, Salim Efendi doesn't have close relationship with his daughter, Aysel.Salim Efendi doesn't want Aysel to have education. Then Salim Efendi decides about Aysel to marry, but this marriage doesn't occur. When the groom sees Aysel talking with her classmates, the groom supposes that they are lovers. Salim Efendi hears this rumour, and he gives up Aysel's marriage. Thanks to the rumour, Aysel continues her education. In terms of family roles, mother-daughter relations Aysel and her mother Fitnat Hanım conflict each other, though Fitnat Hanım is a calm person. While Aysel struggles for her education, Fitnat Hanım wants her to do houseworks. Aysel thinks that her mother feels anger, as Aysel can have education. In terms of family roles, brother-sister relations, Aysel conflicts with her older brother İlhan, too. İlhan objects Aysel's education, as well. All of their life, İlhan and Aysel have conflicted. Aysel have gotten angry with her parents, because they behave as if they had only a son. Aysel wants her parents to remind herself as an individual.

Aysel achieves her goal she becomes a professor at the university in the end. She marries Ömer.Ömer is a professor at the university, too. After a while, they conflict in their marriage. Then, Aysel has relation with her student Engin.Aysel has difficulty in all her relations. Therefore, she queries all her life with suicidal ideation in a hotel room.

Adalet Ağaoğlu, creates an independent, strong woman from a shy, strong-minded, little girl. While Aysel was at the primary school, she was shy to her classmates, Aydın, Ali and Ertürk. She didn't want to meet her classmates, especially Aydın, who was a son of the bureaucrat, while she did her houseworks. Adalet Ağaoğlu criticizes the Republican Era due to authorities 's citizen thoughts. Education for bureaucrat's family was easier than public. But taking education is difficult for public, especially Aysel struggles to take education. In some areas, like education, public and authorities have conflict.

One of the writers for this study is a contemporary writer Ayfer Tunç.Ayfer Tunç tells Şebnem's story, in her novel "Yeşil Peri Gecesi". After a bad traffic accident, Şebnem's father feels very bad. As he has got injured badly. This accident devastates Şebnem's nucleus family. Before this accident, Şebnem is happy with her family. In terms of family roles, father-daughter and mother-daughter relations, Şebnem has close relation with both her parents in her childhood. After Şebnem's father accident, her parents get divorced. Then Şebnem's mother get married another man. Şebnem's step father treats her badly. Then Şebnem lives her father again, and her mother gets divorced, marries other man and moves to Germany. Shadows of all events, other family members behave Şebnem badly. Şebnem's grandmother and aunt doesn't like her and her mother. Because Şebnem looks like her mother who is beautiful. Şebnem thinks of her beauty as a punishment. In fact, everybody treats her very badly. Her thoughts about her beauty cause her become a cover girl. Her psychological problems also cause her become a cover girl. After her boyfriend Ali leaves her, 
she gets married Osman. But this marriage doesn't take a long time. Even though they have a good relationship at first, they lose their love and respect with each other. This novel shows that there is duplicity about women. Men value some notions such as morality, honour, family. However, they want to have relation with her otherwise they accept her as a cover girl.

Women struggle to promote their rights. Even their struggle goes on. Families become nucleus family from extended family. Women's historical struggle go on in society as women.

\section{WOMEN, IN TERMS OF EDUCATION AND WORK LIFE}

Education is the second area for people to become socialized. Education does not gain people knowledge and skill but also serves social purposes. Therefore, the society becomes a member of international area. Education can either decrease inequality or increase. This study dwelled on how education has an effect upon gender differences by analysing novels in point.

Women 's right to education was limited in the Ottoman Era. With the Tanzimat Reforms, secondary schools and teacher's training schools were opened for women at the first time. Some families provided education for their daughter to take private lessons, like Fatma Aliye's family. Fatma Aliye translated George Ohnet's the novel which is called "Volonte" from French to Turkish. But everybody was surprised how the woman translated such a novel. That success wasn't surprising, thanks to Fatma Aliye's eagerness to learn and Ahmed Cevdet Pasha's support, her daughter Fatma Aliye succeed. While Fatma Aliye's brother took his private lesson, she listened to the lesson behind the door. Then she became an assistant of her brother voluntarily at chemistry lesson in laboratory. In her novel "Muhadarat", Fazıla also take private lessons thanks to her father's support. She speaks French fluently and she can play the piano. Fatma Aliye emphasises on her novels that women have education and appear in society. The Ottoman first women writer Fatma Aliye wrote many essays and novels, made translations so that she was a pioneer for women movements, when there were gender differences in society.

In 1842, women had a nursing education based on medical faculty. Apart from this, secondary school was opened for women in 1858.Women also had an education at school of industry in 1869.Moreover, teacher's training schools provide women the opportunity as work teacher in 1870. When the first constitutional law, Kanun-i Esasi, announced in 1876, women and men had an opportunity for compulsory primary education. In 1911, high schools were opened. In 1914, the university for women that was named İnas Darül Fünunu was opened (Yumuşak, 2010, s. 153).

The Republican Era also made reforms on education with the announcement of the republic. The republican authorities made law on education that was named Tevhid-i Tedrisat on 3 March 1924.That law changed educational system. Because there were differences educational system in the Ottoman Empire. The republican authorities gave importance for women's education and get a job. But the Republican authorities were criticized about jobs for women. Because these jobs for women emphasized maternity more than provide earning a living. Besides the Republican authorities cause that women were only located in private patriarchy. The republican authorities also criticized that they cause gender discrimination on jobs opportunity, as the Tanzimat Era did. Furthermore, Code of Law was criticized about right to labour because women need their husband approvals to work (Arat, 1998, s. 57).

Adalet Ağaoğlu is one of them who criticized the Republican authorities. She criticizes the Republican authorities with her novel character Aysel in" Ölmeye Yatmak". Even though Aysel becomes a sociology professor with her immense struggle, people always behave her only as a woman. Then she is disappointed for this situation. Even if the Republican authorities found a new state, they continue patriarchal structure (Berktay, 1998, s. 5).

More women have an opportunity for education nowadays. Even though there have been some problems, acquirements are more than in past. Women can get jobs whatever they want, although gender discrimination and patriarchy goes on. In Ayfer Tunç's "Yeşil Peri Gecesi", although Şebnem has an opportunity for her education, she doesn't go on her education after graduating high school. Ayfer Tunç also evaluated the relations between women's education and family and social problems. Ayfer Tunç gives an example of educated women by Şebnem's relative who is a journalist, is Selda.

When women work with men in social life, this trigger progress of country like developed countries. The Industrial Revolution made division of labour in labour relations. Moreover, the Industrial Revolution made both division of labour and gender discrimination. In order to reduce the cost, women were preferred. Even though women made same works with men, they were exploited by having ill pay.

Women contributed to industrialization in the Ottoman Era. Women were also unpaid family worker, before 
industrialization; for example, there were 121 women worker at match factory in Istanbul, in 1898.Since wars lead to labour loss, women's employment participation rate increased. In 1913, women employees' rate were $\% 20$ in industry sector, then women employees 's rate were \%30 in 1915. The Ottoman women also highlight the importance of work on their publications and association (Çakır, 2011, s. 363).

Fatma Aliye also highlights the importance of work in her novel. In her other novel "Udi" the main character Bedia plays the oud, so she earns her living with the oud. In another novel, Refet, Refet is a teacher. Within the scope of this study, "Muhadarat" were analysed. The main character Fazıla worked as nanny. Even though the Ottoman authorities made gender discrimination, they opened many schools for women. They contributed women to earn their living at the least.

The Republican authorities provided equality of women and men with both reforms and laws. Even if gender discrimination continued, after the first women generation of Republican Era had taken education in many different areas, they got a job in many different areas. In Adalet Ağaoğlu's novel "Ölmeye Yatmak" shows although Aysel becomes financially independent, she doesn't gain social equality. Even if Aysel carries out idea of her generation about education and work, she gets disappointed mostly.

Women also struggle to take part in her private space and public space with their labour nowadays. There are many women in every occupational group. However, current labour data indicated that women employment need to increase. While women's labour force participation rate was $\% 32,4$, men's labour force participation rate was \%72,8 (tüik, 2015).

In order to promote women employment, authorities can encourage women with more active politics. To be a woman or to be a mother doesn't prevent them in labour relations. Authorities, also don't allow gender discrimination and they monitor to the boss. Both women and men can contribute to labour relations by using their different properties. Amartya Sen says with his "Capability Approach" that problems in labour relations can be solved with the different contributions of women and men (Kılıç, 2010, s. 338).

\section{WOMEN, IN TERMS OF POLITICS AND FREEDOM}

In order to contribute to problems of society and provide more freedom are for themselves, women try to participate in politics. They have tried to decide about themselves, as the subject, even though men have decided about them throughout the history. Since women want to be forceful in political, social and economic area, women are prevented mostly; for fear that men can lose their sovereign.

Fatma Aliye became a writer, therefore, she was the voice of women. She stressed with her novels and essays that women's education and getting a job was important. According to her, women benefited from individual rights and freedoms equally with men. As Fatma Aliye was one pioneer of the women rights, she upholds that freedom was obtained. Moreover, Fatma Aliye's Era was named the first wave of the feminism. For this reason, firstly Fatma Aliye and other women struggled to education, freedom and equality (Zihnioğlu, 2013, s. 53).

Before announcement of the Republic, women fought for Turkish war of Independence with men against the enemy forces. When the republic was founded, women obtained rights with reforms. They gained right of voting in local elections in 1930 and they gained right of voting in general election on 5 December 1934. However, when researchers studied on these rights, a question occurred. "Did women struggle to gain for their rights or only authorities give women rights?"

Researchers discussed about rights in the light of that question. For instance, one of the pioneers of rights was Nezihe Muhiddin.Nezihe Muhhiddin and other pioneer women founded Women 's People Party to participate in politics for the political and social rights of women. However, they dissolved Women's People Party, due to the political situation during the time. Then they founded Turkish Women's Union. They defended equality of women and men, equal pay for equal work and women's political engagement. Moreover, they nominate the candidate in election, but they weren't successful. Media organs also exhibited an attitude in gender discourse way toward Turkish Women's Union. Political power of the Republican Era wanted women to stay in the area that was only identified by the political power. Political power also emphasised that they gave already rights to women with the proclamation of the republic. Otherwise women claimed rights, political power thought that women discriminated against the political power. Thus, Women's People Party was dissolved and Turkish Women's Union dissolved by itself (Zihnioğlu, 2013, s. 262).

Adalet Ağaoğlu also criticizes the political power. Even though reforms were made, there was patriarchy in society. Adalet Ağaoğlu says in her one of conversations that "I need to review to the Republic. If you read my novels carefully, there aren't any advices in the end of my novels. I don't pull the door by closing on life. I avoid giving advices. I also avoid that this is the only truth" (Andaç, 2005, s. 130). 
On the other hand, Nermin Abadan Unat interpret differently the approaches on women problems of the Republican authorities. She says that "The republican authorities aim at equal citizenship. It doesn't mean the Republican authorities don't give importance for women problems" (Unat, 1998, s. 329).

After military coup in 1980, feminism put forward that women's problem must examine with a different perspective. Feminism became stronger than other political ideologies. Women were organized as left -wing feminists and Islamist feminists, etc. They started new discussions about women's freedom in male dominated both left-wing and right -wing politics. Women made equality of women and men a current issue. Then they stated that gender discrimination was human rights violation. To benefit all rights which didn't benefit until that days, women demanded positive discrimination. Beside this, women discussed gender roles and family regarded as taboo. Women pointed that only mothers didn't have responsibilities on children and family. Men could have also responsibilities on children and family. In addition, women must be supported. For this purpose, 10 th article of the constitution was rearranged. Then Ministry of Family and Social Policies was founded. Nevertheless, there has been the discussion about the name of ministry. It is suggested that the name of ministry must change as Ministry of Women and Social Policies. Moreover, Turkish Grand National Assembly drew attention how women rights to promote in social, political and economic area by committee on equality of opportunity for women and men. Women are not only mother or wife, but also they are individual. However, discussions go on different areas and different ways.

After 1980 and until nowadays women movements questioned how state had attitude toward women. Women movements moved as women centred, they were organized on different political views (Çaha, 1996, S. 138).

Ayfer Tunç criticizes the opinion that women's bodies are the object. Ayfer Tunç tells perspective about women with her novel "Yeşil Peri Gecesi "and the character Şebnem of novel. As Şebnem was a cover girl in the past, when she least expects it, she faced with her past.

Ayfer Tunç mentions the origins of the word "power" in one of her conversations. She says that the word "power" derived from the word "destiny" in Arabic. Therefore, men try to seal women's destiny in society. Men behave women at home like the divine will, thus they try to make insignificant women (Inci, 2014, s. 297).

Women struggled for their rights, they still have struggled. In order to solve women's problems, authorities should support to women's political representation and authorities should make more active social policies about women's problems. Women struggle to reveal their presence on their own, as individual. The last word should only be told by women not by men. Arrangements made by the men should not be sanctified. It is inevitable that the male-dominated of society is eliminated.

Women's freedom is closely related to the elimination of gender differences. Women should preserve their differences and their identity as women. They also ensure adoption by society (Akal, 1994, s. 125).

\section{RESULTS}

Literature enlightens social changes. This study also evaluated novels that showed women problems by women writers in their periods. This study analysed women's problems in three periods. These periods were the Ottoman Era, the Republican Era and the contemporary.

Women did not only struggle on their private space, but also they struggled to take part in all spaces with men. They overcame limits both private and public space. They wanted to determine limits on their own.

As women procreative and bring up children, male -dominated society is concerned about women in all times. Men decide on how women live, how women wear, which roles women can have. The political power discusses from these point. When women noticed their femaleness doesn't prevent them to be in social, political and economic area, they struggle to change society's perspective on women.

Women who cope with problems both family and social life in three difference time, they gain strength in society. Even though women have problems, they overcome the difficulties, as they learned their fighting history. In conclusion, women can overcome gender differences and inequality through their strong identity and awareness.

\section{REFERENCE LIST}

Ağaoğlu, A. (2014). Ölmeye Yatmak. İstanbul: Everest Yayınları.

Akal, C. B. (1994). Siyasi Iktidarın Cinsiyeti. Ankara: Imge Kitabevi Yayınları. 
Andaç, F. (2005). Adalat Ağaoğlu Kitabı-"Sen Türkiye 'nin En Güzel Kazazısın". İstanbul: Türkiye İş Bankası Kültür Yayınları.

Arat, Z. F. (1998). Kemalizm ve Türk Kadını. A. B. Hacımirzaoğlu içinde, 75 Yılda Kadınlar ve Erkekler (s. 376). İstanbul: Tarih Vakfı Yayınları.

Berktay, F. (1998). Cumhuriyet'in 75 Yıllık Serüvenine Kadınlar Açısından Bakmak. A. B. Hacımirzaoğlu içinde, 75 Yılda Kadınlar Ve Erkekler (s. 375). İstanbul: Tarih Vakfı Yayınları.

Çaha, Ö. (1996). Sivil Kadın. Ankara: Vadi Yayınları.

Çakır, S. (2011). Osmanlı Kadın Hareketi. İstanbul: Metis Yayınları.

Gürbilek, N. (2014). Kör Ayna Kayıp Şark (4.basım b.). İstanbul: Metis Yayınları.

Hanım, F. A. (2011). Muhaderat. İstanbul: Turna Yayınları.

İnci, H. (2014). Ayfer Tunç'la Karanlıkta Kelimeler. İstanbul: Can Yayınları.

Kılıç, A. (2010). Sosyal Politika Reformu Çerçevesinde Kadınlar Ve Vatandaşıık. B. E. Oder, H. Durudoğan , F. Gökşen, \& D. Yükseker içinde, Türkiye 'de Toplumsal Cinsiyet Çalışmaları-Eşitsizlikler Mücadeleler Kazanımlar (s. 332). İstanbul: Koç Üniversitesi Yayınları.

Ortaylı, I. (2013). Osmanlı Toplumunda Aile. İstanbul: Timaş Yayınları.

Tunç, A. (2010). Yeşil Peri Gecesi (2.Basım b.). İstanbul: Can Yayınları.

tüik. (2015, December 5). http://www.tuik.gov.tr/PreHaberBultenleri.do?id=21567. http://www.tuik.gov.tr/PreHaberBultenleri.do?id=21567:

http://www.tuik.gov.tr/PreHaberBultenleri.do?id=21567 adresinden alındı

Unat, N. A. (1998). Söylemden Protestoya:Türkiye 'de Kadın Hareketlerinin Dönüşümü. A. B. Hacımirzaoğlu içinde, 75 Yılda Kadınlar ve Erkekler (s. 373). İstanbul: Tarih Vakfı Yayınları.

Yumuşak, F. C. (2010). Fatma Aliye:Fatma Aliye'nin Eserlerinde Kadın Sorunları. İstanbul: Timaş Yayınları.

Zihnioğlu, Y. (2013). Kadınsız Inkilap. İstanbul: Metis Yayınları. 